\title{
Keragaan F1 dan Heterosis Karakter Agronomis pada Beberapa Persilangan Padi Beras Merah
}

\section{F1 Performances and the Agronomics Characters Heterosis on Several Red Rices Crossing}

\author{
I Gusti Putu Muliarta Aryana*, Anak Agung Ketut Sudarmawan, dan Bambang Budi Santoso \\ Program Studi Agroekoteknologi, Fakultas Pertanian UNRAM \\ Jl. Majapahit No.62 Mataram, NTB 83127, Indonesia
}

Diterima 2 Februari 2017/Disetujui 31 Oktober 2017

\begin{abstract}
Study on the effect of heterosis is important in order to find potential parent for creating a new superior variety. This research was aimed to study the phenotipic expression of $F 1$ and heterosis on agronomics characters some crossed red rice. Experiment was done at a paddy field in Nyurlembang, West Lombok, West Nusa Tenggara during August-November 2016, and it was arranged in a randomized block design of 12 genotypes as treatment with five replications. Genotypes evaluated were Fatmawati, IPB3S, G9(F2BC4P19-36), F1-Fatmawati/Inpago Unram-I, F1-Fatmawati/G9, F1-IPB 3S/Inpago UnramI, F1-IPB 3S/G9, F1-Inpago Unram-I/Fatmawati, F1-G9/Fatmawati, F1-Inpago Unram-I/IPB 3S, and F1-G9/IPB 3S. The results showed that based on the F1 phenotipic performances and heterosis on grain weight per hills, yield, 1000 grain weight, number of grain per panicle, length of panicle, number of productive tiller per hill, and time offlowering, there were three genotypes that had a semi ideal type of red rice with high yield potential. The genotypes were F1-Fat/G9, F1-Inpago Unram-I/IPB 3S, and F1-IPB 3S/Inpago Unram-I.
\end{abstract}

Keywords: diversity, agronomic, yield, red rice

\section{ABSTRAK}

Informasi pengaruh heterosis sangat penting dalam kaitannya dengan penentuan suatu tetua yang potensial untuk pembentukan suatu varietas unggul baru yang berdaya hasil tinggi. Penelitian bertujuan mempelajari ekspresi fenotipe F1 dan heterosis karakter agronomis pada beberapa hasil persilangan padi beras merah. Percobaan dilakukan di lahan sawah desa Nyurlembang, Lombok Barat pada Agustus-Nopember 2016, dengan rancangan acak kelompok diulang lima kali. Dua belas genotipe digunakan sebagai perlakuan, yaitu Fatmawati, IPB 3S, Inpago Unram I, G9(F2BC4P19-36), F1-Fatmawati/ Inpago Unram-I, F1-Fatmawati/G9, F1-IPB 3S/Inpago Unram-I, F1-IPB 3S/G9, F1-Inpago Unram-I/Fatmawati, F1-G9/ Fatmawati, F1-Inpago Unram-I/IPB 3S, dan F1-G9/IPB 3S. Hasil penelitian menunjukkan bahwa berdasarkan keragaan fenotipe F1 dan heterosis karakter bobot gabah per rumpun, hasil, bobot 1,000 butir gabah, jumlah gabah isi per malai, panjang malai, jumlah anakan produktif per rumpun dan umur berbunga, maka genotipe hasil persilangan F1-Fat/G9, F1Inpago Unram-I/IPB 3S; dan F1-IPB 3S/Inpago Unram-I, berpeluang untuk menghasilkan galur-galur harapan padi beras merah semi tipe ideal dengan potensi hasil gabah tinggi.

Kata kunci: keragaman, agronomis, hasil, beras merah

\section{PENDAHULUAN}

Padi merupakan tanaman pangan utama di Indonesia dan kebutuhannya selalu meningkat setiap tahun. Seiring meningkatnya kesadaran terhadap kesehatan maka perakitan varietas unggul padi fungsional beras merah yang memiliki kandungan antosianin mulai diintensifkan (Aryana, 2009). Beberapa varietas padi beras merah yang telah dilepas adalah varietas padi sawah Aek Sibundong, Inpari 24 Gabusan dan padi gogo Inpago Unram I yang semuanya tergolong varietas unggul baru (VUB), namun hingga kini padi beras merah

\footnotetext{
* Penulis untuk korespondensi. e-mail: muliarta1@yahoo.co.id
}

varietas tipe baru (VTB) belum dihasilkan. Salah satu cara yang dapat dilakukan untuk merakit padi beras merah VTB adalah melalui persilangan antar tertua yang terpilih.

Varietas Fatmawati dan IPB 3S adalah VTB yang memiliki warna beras putih, memiliki jumlah anakan sedikit, dan jumlah biji per malai banyak. Varietas Inpago Unram-I dan Galur Harapan G9 (F2BC4P19-36) memiliki warna beras merah, jumlah anakan banyak, namun jumlah bulir per malainya sedikit (Suprihatno et al.,2010; Aryana, 2012).Tetua dengan variasi genetik yang tinggi akan memberikan peluang besar dalam menghasilkan kombinasi persilangan sifat-sifat yang dikehendaki dalam perakitan varietas unggul. 
Keragaan fenotipe karakter agronomis tanaman merupakan ciri morfologi yang sering digunakan sebagai pembeda antar genotipe padi, seperti tinggi tanaman, jumlah anakan produktif dan non produktif, jumlah gabah per malai, bentuk gabah, dan panjang malai. Pemilihan sifat-sifat tersebut dapat dilakukan dengan memanfaatkan ragam fenotipe pada tanaman tersebut. Keragaman karakter fenotipik suatu tanaman adalah keragaman penampilan sifat tanaman pada suatu lingkungan tumbuh merupakan hasil interaksi antara faktor genetik dan lingkungan (Hao et al., 2010; Kumar et al., 2010). Peluang untuk menghasilkan varietas unggul semakin besar jika keragaman fenotipenya tinggi. Fenotipe yang diinginkan beragam, utamanya pada umur panen, tinggi tanaman, panjang malai, bobot 1,000 butir, gabah isi dan potensi hasil (Ishak, 2012; Sutaryo, 2014; Mara et al., 2015),

Heterosis merupakan fenomena biologi yang menunjukkan keunggulan hasil persilangan F1 atau hibrida melebihi kedua tetuanya. Berdasarkan penampilan hibrida $\mathrm{F} 1$, terdapat tiga kriteria heterosis yaitu: mid-parent heterosis yaitu perbandingan rata-rata $\mathrm{F} 1$ dengan nilai rata-rata kedua tetua; heterobeltiosis yaitu perbandingan nilai ratarata F1 dengan nilai rata-rata tetua tertinggi; dan standard heterosis yaitu perbandingan rata-rata $\mathrm{F} 1$ dengan varietas pembanding (Virnani et al., 1991). Penelitian tentang midparent heterosis dan heterobeltiosis pada tanaman padi sebelumnya telah dilakukan oleh beberapa peneliti yang difokuskan pada karakter umur berbunga, umur panen, tinggi tanaman, jumlah anakan produktif dan non produktif, panjang malai, jumlah gabah isi dan hampa, bobot 100 butir gabah dan berat gabah per rumpun (Rahimi at al., 2010, Parera et al., 2013, Ashfaq et al., 2013; Huang et al., 2015). Virnani et al. (1991) dan Darlina et al. (1992) menyatakan bahwa pemilihan tipe kultivar padi yang digunakan sebagai tetua menentukan besarnya heterosis yang diteliti. Efek heterosis pada F1 dalam hibridisasi mempunyai arti yang sangat penting dalam pembentukan suatu varietas hibrida terutama dalam menentukan pemilihan suatu tetua yang potensial untuk membentuk varietas hibrida berdaya hasil tinggi. Penelitian ini bertujuan untuk mempelajari ekspresi fenotipe F1 dan heterosis karakter agronomis pada beberapa hasil persilangan padi beras merah.

\section{BAHAN DAN METODE}

Percobaan dilakukan di lahan sawah Desa Nyur Lembang Kecamatan Narmada kabupaten Lombok Barat pada bulan Agustus sampai dengan Nopember 2016. Percobaan ditata dalam rancangan acak kelompok dengan 12 genotipe padi sebagai perlakuan yang diulang lima kali. Genotipe yang digunakan yaitu empat tetua (varitas Fatmawati, IPB3S, Inpago Unram I, Galur Harapan G9(F2BC4P19-36), dan delapan genotipe F1 hasil silang tunggal (F1- Fatmawati/Inpago Unram 1, F1-Fatmawati/ G9, F1-IPB 3S/Inpago Unram I, F1-IPB 3S/G9, F1-Inpago Unram I/Fatmawati, F1-G9/Fatmawati, F-Inpago unram I/ IPB 3S, dan F1-G9/IPB 3 S).

Penanaman secara budidaya padi sawah dilakukan pada umur bibit 21 hari, dengan jarak tanam $25 \mathrm{~cm} \mathrm{x}$
$25 \mathrm{~cm}$ pada luasan petak perlakuan ukuran $1.5 \mathrm{~m} \mathrm{x} 2 \mathrm{~m}$. Pemupukan dengan $300 \mathrm{~kg} \mathrm{ha}^{-1}$ NPK (15-15-15) diberikan satu minggu setelah tanam, $200 \mathrm{~kg} \mathrm{ha}^{-1}$ Urea diberikan dua kali yaitu pada saat tanaman berumur 30 dan 50 hari setelah tanam. Pengamatan dilakukan terhadap umur berbunga, tinggi tanaman, jumlah anakan produktif dan non produktif per rumpun, panjang malai, jumlah gabah isi dan hampa per malai, bobot 1,000 butir gabah, bobot gabah per rumpun dan hasil (hasil panen per meter persegi dikonversikan ke ha pada kadar air 14\%). Analisa ragam dilakukan menggunakan program SAS, dan dilakukan uji lanjut DMRT (Duncan Multiple Range Test) 5\%.

Analisis heterosis rata-rata kedua tetua (MP)/mid parent heterosis dan heterosis terhadap tetua terbaik (HP)/ heterobeltiosis menggunakan rumus Fehr (1987), sebagai berikut

$M P H(\%)=\frac{F 1-M P}{M P} \times 100 \%$
$H P H(\%)=\frac{F 1-H P}{H P} \times 100 \%$

Keterangan: $\mathrm{MPH}=$ Heterosis berdasarkan ratarata kedua tetua (mid parent heterosis), $\mathrm{HPH}=$ Heterosis berdasarkan tetua tertinggi (heterobeltiosis); F1 = rata-rata kombinasi persilangan; $\mathrm{MP}=$ rata-rata kedua tetua, $\mathrm{HP}=$ rata-rata tetua tertinggi.

Uji efek tetua betina (maternal) terhadap warna pericap beras dilakukan pengamatan terhadap beras F1 dan F1 resiprok.

\section{HASIL DAN PEMBAHASAN}

Hasil analisis ragam menunjukkan bahwa terdapat perbedaan yang nyata pada semua karakter agronomis. Umur berbunga berkisar antara 79.0-87.8 hari setelah semai (hss) dengan nilai rataan 83.2 hss (Tabel 1). Umur berbunga paling cepat ditemukan pada varietas tetua Inpago Unram I yaitu 79.0 hss. Jika dilihat dari penggolongan umur berbunga maka seluruh genotipe yang diuji tergolong berbunga cepat (71-90 hari). Chandrasari et al. (2013) menyatakan bahwa tanaman yang umur berbunganya lebih cepat memiliki fase generatif yang lebih cepat pula, sehingga semakin cepat tanaman padi berbunga maka umur panen akan semakin cepat pula.

Terdapat perbedaan nyata pada tinggi tanaman antar genotipe padi yang diuji. Kisaran tinggi tanaman antara $113.7-131.5 \mathrm{~cm}$ dengan rata-rata $123.6 \mathrm{~cm}$ (Tabel 1). Standar tinggi tanaman yang ditetapkan IRRI untuk padi tipe baru (PTB) paling rendah adalah $100 \mathrm{~cm}$ (Peng et al., 2008), sedangkan tinggi tanaman untuk tanaman tipe ideal menurut Ma et al. (2006) berkisar $115-120 \mathrm{~cm}$. Tinggi tanaman genotipe F1-Fatmawati/G9 $(116.8 \mathrm{~cm})$ berbeda tidak nyata dengan Fatmawati yang dapat digolongkan termasuk tipe ideal. Tinggi tanaman merupakan salah satu kriteria seleksi pada tanaman padi. Zen (2013) menambahkan bahwa tanaman yang pendek akan terhindar dari kerebahan akibat angin, sehingga tanaman yang demikian mudah dirawat.

Jumlah anakan produktif per rumpun berkisar 1027 batang dengan rata-rata 16.1 batang. Rata-rata jumlah 
Aryana et al. / J. Agron. Indonesia 45(3):221-227

Tabel 1. Karakter reproduktif genotipe hasil persilangan Fatmawati dan IPB 3S dengan padi beras merah

\begin{tabular}{|c|c|c|c|c|c|c|c|c|c|c|}
\hline Genotipe & UB & TT & JAP & JANP & $\mathrm{PM}$ & JGI & JGH & B1000 & BGPR & $\mathrm{H}$ \\
\hline Fatmawati & $84.8 b^{*}$ & $113.7 \mathrm{e}$ & $9.8 \mathrm{~g}$ & $0.0 \mathrm{~b}$ & $27.7 \mathrm{a}^{*}$ & $215.3 \mathrm{a}$ & $51.2 \mathrm{a}$ & $29.0 \mathrm{a}$ & $70.8 \mathrm{ab}$ & $9.2 \mathrm{ab}$ \\
\hline IPB $3 \mathrm{~S}$ & $85.8 \mathrm{ab}$ & $119.5 \mathrm{bcde}$ & $10.8 \mathrm{~g}$ & $0.0 \mathrm{~b}$ & $27.9 \mathrm{a}$ & $218.3 \mathrm{a}$ & $42.9 \mathrm{a}$ & $28.7 \mathrm{ab}$ & $74.7 \mathrm{a}$ & $9.8 \mathrm{a}$ \\
\hline Inpago Unram I & $79.0 \mathrm{e}$ & $127.2 \mathrm{abc}$ & $26.5 \mathrm{a}$ & $1.5 \mathrm{a}$ & $23.0 \mathrm{~cd}$ & $163.4 \mathrm{~b}$ & $17.0 \mathrm{~d}$ & $25.7 \mathrm{e}$ & $77.8 \mathrm{a}$ & $10.4 \mathrm{a}$ \\
\hline G9(F2BC4P19-36) & $81.2 \mathrm{~d}$ & $118.8 \mathrm{cde}$ & $20.2 \mathrm{bc}$ & $1.5 \mathrm{a}$ & $22.3 \mathrm{~d}$ & $153.9 b$ & $24.1 \mathrm{bcd}$ & $27.8 \mathrm{abc}$ & $60.3 b c$ & $7.6 \mathrm{bc}$ \\
\hline F1- Fatmawati/Inpago Unram I & $85.7 b$ & $125.2 \mathrm{abcd}$ & $15.3 \mathrm{def}$ & $0.0 \mathrm{~b}$ & $27.2 \mathrm{ab}$ & $216.1 \mathrm{a}$ & $26.9 \mathrm{bcd}$ & $27.5 \mathrm{bcd}$ & $71.7 \mathrm{ab}$ & $9.4 \mathrm{ab}$ \\
\hline F1- Fatmawati/ G9 & $84.2 \mathrm{bc}$ & $116.8 \mathrm{de}$ & $14.7 \mathrm{ef}$ & $0.0 \mathrm{~b}$ & $27.2 \mathrm{ab}$ & $214.1 \mathrm{a}$ & $32.8 b$ & $28.9 \mathrm{a}$ & $69.2 \mathrm{ab}$ & $9.0 \mathrm{ab}$ \\
\hline F1- Inpago Unram I/Fatmawati & $82.3 \mathrm{~cd}$ & $131.0 \mathrm{a}$ & $18.5 \mathrm{bcd}$ & $0.2 b$ & $25.1 \mathrm{bc}$ & $169.7 b$ & $22.7 \mathrm{bcd}$ & $27.0 \mathrm{cde}$ & $74.0 \mathrm{a}$ & $9.7 \mathrm{a}$ \\
\hline F1- G9/Fat & $87.8 \mathrm{a}$ & $122.0 \mathrm{abcd}$ & $16.8 \mathrm{cde}$ & $0.3 b$ & $24.3 \mathrm{~cd}$ & $157.3 b$ & $17.8 \mathrm{~cd}$ & $28.6 \mathrm{ab}$ & $56.2 \mathrm{c}$ & $6.9 \mathrm{c}$ \\
\hline F1- IPB 3S/Inpago Unram I & $82.3 \mathrm{~cd}$ & 124.7abcd & $13.0 \mathrm{fg}$ & $0.0 \mathrm{~b}$ & $27.3 \mathrm{ab}$ & $223.7 \mathrm{a}$ & $21.8 \mathrm{bcd}$ & $28.5 \mathrm{ab}$ & $76.7 \mathrm{a}$ & $10.2 \mathrm{a}$ \\
\hline F1- IPB 3S/G9 & $82.2 \mathrm{~cd}$ & $123.5 \mathrm{abcd}$ & $11.8 \mathrm{fg}$ & $0.0 \mathrm{~b}$ & $27.3 \mathrm{ab}$ & $217.3 \mathrm{a}$ & $28.9 \mathrm{bc}$ & $29.0 \mathrm{a}$ & $69.2 \mathrm{ab}$ & $9.0 \mathrm{ab}$ \\
\hline F1- Inpago Unram 1/IPB 3S & $81.8 \mathrm{~d}$ & $128.8 \mathrm{ab}$ & $21.0 \mathrm{~b}$ & $0.2 b$ & $23.3 \mathrm{~cd}$ & $165.5 b$ & $17.3 \mathrm{~cd}$ & $26.2 \mathrm{de}$ & $78.7 \mathrm{a}$ & $10.5 \mathrm{a}$ \\
\hline F1- G9/IPB 3S & $82.2 \mathrm{~cd}$ & $131.5 \mathrm{a}$ & $14.8 \mathrm{ef}$ & $0.2 b$ & $22.9 \mathrm{~cd}$ & $144.2 \mathrm{~b}$ & $25.9 \mathrm{bcd}$ & $28.8 \mathrm{ab}$ & $57.3 \mathrm{c}$ & $7.1 \mathrm{c}$ \\
\hline Rerata & 83.3 & 123.6 & 16.1 & 0.3 & 25.5 & 188.2 & 27.5 & 28.0 & 69.7 & 9.1 \\
\hline Maksimum & 87.8 & 131.5 & 26.5 & 1.5 & 27.9 & 223.7 & 51.6 & 29.0 & 78.7 & 10.5 \\
\hline Minimum & 79.0 & 113.7 & 9.8 & 0.0 & 22.3 & 144.2 & 17.0 & 25.7 & 56.2 & 6.9 \\
\hline
\end{tabular}

Keterangan: * = Angka yang diikuti huruf sama pada kolom sama tidak berbeda pada uji DMRT 5\%, UB = Umur berbunga (hari setelah semai), UP = Umur panen (hari setelah semai); TT = Tinggi tanaman $(\mathrm{cm})$; JAP = Jumlah anakan produktif per rumpun (batang); JANP = jumlah anakan non produktif per rumpun (batang); PM = Panjang malai $(\mathrm{cm})$; JGI = Jumlah gabah isi per malai (butir); JGH = Jumlah gabah hampa per malai (butir); B1000 = Berat 1,000 butir gabah isi (g); BGPR = Berat gabah per rumpun $(\mathrm{g}) ; \mathrm{H}=$ Hasil gabah kering giling $\left(\right.$ ton $\left.\mathrm{ha}^{-1}\right)$

anakan produktif terendah dijumpai pada Fatmawati $(9.8$ batang), IPB 3S (10.8 batang), F1-IPB 3S/Inpago Unram-I (13.0 batang), dan F1-IPB 3S/G9 (11.8 batang). Sementara genotipe yang menghasilkan jumlah anakan produktif tinggi sebanyak 26.5 batang adalah Inpago Unram-I (Tabel 1). Thamrin et al. (2010) menyatakan bahwa anakan produktif per rumpun merupakan penentu jumlah malai. Dengan demikian anakan tersebut berpengaruh langsung terhadap tinggi rendahnya hasil gabah. Jumlah anakan non produktif tertinggi nampak pada tetua Inpago Unram-I dan G9(F2BC4P19-36). Thamrin et al. (2010) menyatakan bahwa anakan non produktif merupakan pesaing dari anakan produktif dalam memanfaatkan energi sinar matahari dan unsur hara. Selain itu, semakin banyak anakan non produktif akan menyebabkan lingkungan mikro yang semakin lembab sehingga memberi peluang bagi perkembangan hama dan penyakit.

Panjang malai merupakan kriteria seleksi tanaman padi karena berpengaruh terhadap hasil. Karakter panjang malai berkaitan dengan produksi. Kisaran panjang malai antara 22.3-27.9 cm, dengan rata-rata $25.5 \mathrm{~cm}$ (Tabel 1). Malai terpanjang ditunjukkan oleh tetua Fatmawati $(27.7 \mathrm{~cm})$, IPB $3 \mathrm{~S}(27.9 \mathrm{~cm})$, dan hasil persilangan F1-Fatmawati/Inpago Unram-I $(27.2 \mathrm{~cm})$, F1-Fatmawati/G9 $(27.1 \mathrm{~cm})$, F1-IPB 3S/Inpago Unram-I (27.3), dan F1-IPB 3S/G9 (27.3 cm).

Jumlah gabah isi per malai berkisar 144.2-223.7 butir dengan rata-rata 188.2 butir (Tabel 1). Genotipe yang memiliki jumlah gabah isi tertinggi adalah tetua Fatmawati (215.3 butir), IPB 3S (218.9 butir), dan hasil persilangan yaitu F1-Fatmawati/Inpago Unram-I (216.1 butir ), F1Fatmawati/G9 (214.1 butir), F1-IPB 3S/Inpago Unram-I
(223.7 butir), dan F1-IPB 3 S/G9 (217.3). Zhengjin et al. (2005) mengembangkan padi tipe ideal dengan jumlah gabah isi per malai lebih dari 200 butir. Bobihoe dan Nafisah (2008) menambahkan bahwa jumlah gabah isi per malai berkorelasi dengan hasil tanaman tetapi dipengaruhi juga oleh gabah hampa. Selanjutnya hasil padi ditentukan oleh komponen hasil seperti jumlah gabah isi per malai dan berat 1,000 butir. Jumlah gabah hampa paling tinggi dijumpai pada Fatmawati (51.6 butir) dan IPB 3S (42.9) (Tabel 1). Tingkat kehampaan gabah selain merupakan pengaruh genetik, juga dapat dipengaruhi oleh faktor lingkungan. Peng et al. (2008) menyatakan bahwa rendahnya pengisian biji diakibatkan karena apikal dominan yang kecil pada malai, susunan gabah pada malai, dan terbatasnya seludang pembuluh untuk pengangkutan asimilat. Ekeleme et al. (2007) menambahkan bahwa gulma dapat menurunkan hasil gabah isi hingga $80 \%$, karena gulma menjadi kompetitor dalam penyerapan nutrisi tanah dan kebutuhan cahaya matahari untuk fotosisntesis. Bobot 1,000 butir gabah isi berkisar 25.7-29.0 g dengan rata-rata $28.0 \mathrm{~g}$. Bobot gabah tertinggi dijumpai pada tetua Fatmawati kemudian diikuti oleh IPB 3S, G9, dan turunan hasil persilangan yaitu F1-Fatmawati/ G9, F1-G9/Fatmawati, F1-IPB 3S/Inpago Unram-I, F1IPB 3S/G9 dan F1-G9/IPB 3S (Tabel 1). Menurut Ma et al. (2006) untuk padi tipe ideal dibutuhkan bobot 1,000 butirnya antara 28-30 g. Hasil persilangan yang mendekati Fatmawati dan IPB 3S (tipe ideal) adalah F1-Fatmawati/G9, F1-G9/Fatmawati, F1-IPB 3S/Inpago Unram-I, F1-IPB 3S/ G9, dan F1-G9/IPB 3S.

Tabel 1 menunjukkan pula bahwa F1-Fatmawati/ Inpago Unram-I, F1-Fatmawati/G9, F1-Inpago Unram- 
I/Fatmawati, F1-IPB 3S/Inpago Unram-I, F1-IPB 3S/G9 dan F1-Inpago Unram-I/IPB 3S memiliki bobot gabah per rumpun dan hasil sama dengan tetua Fatmawati, IPB 3S dan Inpago Unram-I. Galur-galur tersebut berpotensi berdaya hasil tinggi. Hasil penelitian Yang et al. (2007) menunjukkan bahwa untuk dapat meningkatkan hasil pada padi dibutuhkan tetua yang memiliki karakter jumlah gabah isi yang banyak dan ukuran malai panjang. Ma et al. (2006) menambahkan jumlah gabah isi per malai untuk karakter padi tipe ideal berkisar antara 180-240 butir dengan gabah isinya lebih dari $85 \%$. Islam et al. (2010) menambahkan jumlah gabah isi per malai disamping karena pengaruh panjang malai, juga karena translokasi karbohidrat dari organ vegetatif ke malai selama periode pengisian gabah isi.

Terdapat empat F1 yang memiliki nilai mid parent heterosis negatif dan $4 \mathrm{~F} 1$ yang memiliki nilai heterosis positif untuk karakter umur berbunga (Tabel 2). F1-IPB 3S/ G9 dan F1-G9/IPB 3S memberikan nilai negatif tertinggi dengan nilai $-1.6 \%$, sedangkan berdasarkan heterobeltiosis semua F1 memberikan nilai negatif kecuali F1-Fatmawati/ Inpogo Unram-1 dan F1-G9/Fatmawati memberikan nilai positif. F1-Inpago Unram-1/IPB 3S memiliki nilai negatif tertinggi $(-4.7 \%)$. Hal ini menunjukkan terdapat pengurangan umur berbunga, artinya tanaman tersebut berbunga lebih cepat dibandingkan dengan rata-rata kedua tetuanya maupun tetua tertingginya. Dengan umur berbunga lebih cepat, maka seleksi akan dilakukan pada tanaman yang lebih cepat berbunga atau lebih cepat panen. Hal ini sejalan dengan pernyataan Ismunadji et al. (1988) yaitu tanaman yang berbunga lebih cepat memiliki fase generatif yang lebih cepat pula sehingga umur panen akan semakin cepat. Hasil penelitian ini sejalan dengan Perera et al. (2013), yaitu hasil persilangan tunggal padi Bg 379-2 x Bw 400 menghasilkan umur panen lebih cepat dibandingkan dengan kedua tetuanya.

Semua F1 memiliki nilai mid parent heterosis positif pada tinggi tanaman, dan tiga F1 memiliki nilai heterobeltiosis negatif serta lima yang positif. Heterobeltiosis terendah didapat pada F1-Fatmawati/Inpago sebesar -1.6\%, F1-Fatmawati/G9 sebesar $-1.7 \%$ dan F1-IPB 3S/Inpago sebesar $-1.9 \%$ (Tabel 2).

Semua F1 memiliki nilai mid parent heterosis dan heterobeltiosis negatif untuk jumlah anakan produktif per rumpun, kecuali F1-Fatmawati/G9 dan F1-G9/Fatmawati memiliki nilai mid parent heterosis positif yaitu sebesar $4.5 \%$ dan $13.3 \%$. Pada jumlah anakan non produktif per rumpun semua F1 memberikan nilai mid parent heterosis dan heterobeltiosis negatif, artinya F1 yang dihasilkan memberikan jumlah anakan non produktif yang semakin rendah per rumpun tanamannya. Jumlah anakan yang sedikit tanpa adanya anakan non produktif merupakan salah satu ciri kriteria dari padi tipe ideal (Yunita dan Harnowo, 2010). Fatimaturrohmah et al. (2016) menambahkan untuk perakitan tanaman padi adalah yang memiliki jumlah anakan produktif yang sedikit hingga sedang agar fotosintat dapat diarahkan untuk pembentukan gabah bernas, jumlah anakan produktif yang diimbangi karakter malai yang panjang dapat mempengaruhi jumlah gabah isi sehingga meningkatkan hasil produksi. Untuk karakter panjang malai, F1 yang memberikan nilai mid parent heterosis positif adalah F1Fatmawati/Inpago Unram-1, F1-Fatmawati/G9, F1-IPB 3S/ Inpago Unram-I, dan F1-IPB 3S/G9 secara berurutan bernilai $7.3 \% ; 8.5 \% ; 6.9 \%$; dan $8.7 \%$. Panjang malai sangat erat kaitannya dengan jumlah gabah isi. Pembentukan padi tipe ideal sangat diharapkan menghasilkan malai yang panjang disertai jumlah gabah isi yang tinggi. Herawati et al. (2009) menyatakan bahwa panjang malai memiliki korelasi positif dengan jumlah gabah per malai. Makarim dan Suhartatik (2009) menambahkan semakin panjang malai tanaman padi maka semakin banyak gabah yang akan dihasilkan.

Karakter jumlah gabah isi per malai (Tabel 3) menunjukkan bahwa terdapat empat F1 yang memberikan nilai mid parent heterosis positif dan empat F1 memberikan nilai heterosis negatif. Hampir semua F1 memberikan

Tabel 2. Heterosis berdasarkan rerata kedua tetua (mid parent heterosis) dan berdasarkan tetua tertinggi/heterobeltiosis (high parent heterosis) pada umur berbunga, tinggi tanaman, jumlah anakan produktif, jumlah anakan non produktif dan panjang malai

\begin{tabular}{lcccccccccc}
\hline & \multicolumn{3}{c}{ UB } & \multicolumn{3}{c}{ TT } & \multicolumn{3}{c}{ JAP } & \multicolumn{3}{c}{ JANP } & \multicolumn{3}{c}{ PM } \\
\cline { 2 - 11 } Genotipe & MP & HP & MP & \multicolumn{1}{c}{ HP } & MP & HP & MP & HP & MP & HP \\
& $(\%)$ & $(\%)$ & $(\%)$ & $(\%)$ & $(\%)$ & $(\%)$ & \multicolumn{1}{c}{$(\%)$} & $(\%)$ & $(\%)$ & $(\%)$ \\
\hline F1-Fatmawati/Inpago Unram I & 4.5 & 0.9 & 3.9 & -1.6 & -21.4 & -47.5 & -100.0 & -100.0 & 7.3 & -1.8 \\
F1-Fatmawati/ G9 & 1.4 & -1.7 & 0.5 & -1.7 & 4.5 & -22.3 & -100.0 & -100.0 & 8.5 & -2.1 \\
F1-Inpago Unram I/Fatmawati & 0.5 & -2.9 & 8.8 & 3.0 & -11.9 & -41.1 & -77.3 & -88.7 & -1.2 & -9.6 \\
F1-G9/Fatmawati & 5.8 & 3.5 & 4.9 & 7.3 & 13.3 & -15.7 & -56.0 & -78.0 & -2.8 & -12.3 \\
F1-IPB 3S/Inpago Unram I & -0.1 & -0.1 & 1.1 & -1.9 & -35.0 & -55.4 & -100.0 & -100.0 & 6.9 & -2.6 \\
F1-IPB 3S/G9 & -1.6 & -1.6 & 3.6 & 3.4 & -23.7 & -41.4 & -100.0 & -100.0 & 8.7 & -2.4 \\
F1-Inpago Unram 1/IPB 3S & -0.7 & -4.7 & 4.5 & 1.3 & -5.0 & -34.9 & -77.3 & -88.7 & -8.5 & -16.6 \\
F1-G9/IPB 3S & -1.6 & -4.3 & 10.4 & 10.0 & -4.3 & -26.5 & -77.3 & -88.7 & -8.6 & -17.8 \\
\hline
\end{tabular}

Keterangan: UB $=$ Umur berbunga, TT $=$ Tinggi tanaman, JAP $=$ Jumlah anakan produktif per rumpun; JANP $=$ Jumlah anakan non produktif per rumpun; $\mathrm{PM}=$ panjang malai; $\mathrm{MP}=$ heterosis berdasarkan rerata kedua tetua (mid parent heterosis); $\mathrm{HP}=$ heterosis berdasarkan tetua tertinggi/heterobeltiosis (high parent heterosis) 
nilai heterobeltiosis negatif kecuali F1-Fatmawati/Inpago Unram-I dan F1-IPB 3S/Inpago Unram-I memberikan nilai positif. Nilai mid parent heterosis dan heterobeltiosis positif tertinggi jumlah gabah isi per malai dijumpai pada F1-IPB 3S/Inpago Unram-I secara berurutan sebesar $17.1 \%$ dan 2.5\%. Nilai mid parent hererosis positif lainnya nampak pada F1-IPB3S/G9, F1-Fatmawati/G9 dan F1-Fatmawati/ Inpago Unram-I secara berurutan sebesar 16.8\%, 15.9\%, dan 14.1\%. Semua F1 memiliki nilai mid parent heterosis dan heterobeltiosis negatif untuk karakter jumlah gabah hampa per malai. Nilai mid Parent heterosis dan heterobeltiosis jumlah gabah hampa per malai terendah terdapat pada F1-G9/Fatmawati sebesar $-52.9 \%$ dan $-65.4 \%$. Adanya peningkatan jumlah gabah isi yang dihasilkan dari hasil persilangan ini sangat diharapkan dalam pembentukan padi tipe ideal. Dewi et al. (2015) menyatakan bahwa jumlah gabah isi dan gabah hampa per malai merupakan salah satu karakter agronomi yang pertama diseleksi dalam kriteria membentuk padi tipe ideal.

Bobot 1,000 butir gabah pada F1 memberikan nilai mid parent heterosis positif namun pada F1-Inpago UnramI/Fatmawati dan F1-Inpago Unram-I /IPB 3S memberikan nilai heterosis negatif. Berdasarkan nilai heterobeltiosis (Tabel 3) menunjukkan semua F1 memberikan nilai negatif kecuali F1-IPB 3S/G9 dan F1-G9/IPB 3S yang memberikan nilai positif. F1-IPB 3S/Inpago memberikan nilai mid parent heterosis positif sebesar $4.8 \%$, sedangkan berdasarkan nilai heterobeltiosis nampak F1-IPB 3S/G9 memiliki nilai positif sebesar $1.1 \%$.

Bobot gabah per rumpun merupakan karakter hasil terpenting pada tanaman padi. Tabel 3 menunjukkan bahwa empat F1 memiliki mid parent heterosis positif dan empat F1 yang memiliki nilai negatif. Berdasarkan penilaian heterobeltiosis semua F1 memiliki nilai negatif kecuali F1-Inpago Unram-I/IPB 3S bernilai heterobeltiosis positif. Munculnya efek heterosis disebabkan akumulasi gen dominan, sedangkan heterobeltiosis tidak lepas dari adanya efek dominan lebih (over dominant) pada karakter tersebut (Nasir, 1999). Tulu (2001) menambahkan bahwa nilai heterosis dipengaruhi keragaman dan jarak genetik tetua yang digunakan. Nilai heterosis yang tinggi, melebihi rata-rata kedua tetuanya atau bahkan tetua terbaiknya menandakan keragaman genetik yang luas di antara individu dalam populasi. Tabel 3 menunjukkan bahwa nilai mid parent heterosis terbaik pada berat gabah per rumpun dan hasil dimiliki oleh F1-Fatmawati/G9 sebesar 5.5\% dan 6.9\%; kemudian diikuti oleh F1-Inpago Unram-I /IPB 3S sebesar $3.2 \%$ dan 3.8\%; F1-IPB 3S/G9 sebesar $2.5 \%$ dan $3.1 \%$; dan F1-IPB 3S/Inpago Unram-I sebesar $0.6 \%$ dan $0.7 \%$. Heterobeltiosis terbaik terjadi pada F1-Inpago/IPB 3S yaitu $1.1 \%$, dan $1.3 \%$. Melalui persilangan antara CGMJI4PO2F/ R114002R dihasilkan hibrida terbaik terhadap nilai mid parent heterosis dan heterobeltiosis tertinggi, positif dan melebih $15 \%$ pada hasil dan komponen hasil jumlah gabah isi per malai, jumlah gabah total per malai serta persentase gabah isi per malai yang meningkat (Sholekha et al., 2015).

Warna beras F1 dan resiprok persilangan Fatmawati memiliki warna pericap putih dengan Inpago Unram-I yang memiliki pericap berwarna merah, menghasilkan warna pericap putih dan merah. Demikian pula untuk warna F1 dan resiproknya dari hasil persilangan Fatmawati (pericap putih) dengan G9 (pericap merah), IPB 3S (pericap putih) dengan Inpago Unram-I (pericap merah) dan IPB 3S dengan G9 menghasilkan warna pericap putih dan merah (Tabel 4). Hasil ini menunjukkan tidak adanya pengaruh maternal efek terhadap warna pericap beras. Tidak ada pengaruh tetua betina merupakan indikasi bahwa warna pericap beras dikendalikan oleh gen-gen di dalam inti (Sifianah et al., 2012). Hasil penelitian ini sejalan dengan Rahman et al. (2015) yang melakukan persilangan antara kultivar beras merah hasil koleksi dari China dan beras putih dari IRRI.

Tabel 3. Heterosis berdasarkan rerata kedua tetua (mid parent heterosis) dan berdasarkan tetua tertinggi/heterobeltiosis (high parent heterosis) pada jumlah gabah isi, jumlah gabah hampa, bobot 1,000 butir, bobot gabah per rumpun, dan hasil

\begin{tabular}{|c|c|c|c|c|c|c|c|c|c|c|}
\hline \multirow[b]{2}{*}{ Genotipe } & \multicolumn{2}{|c|}{ JGI } & \multicolumn{2}{|c|}{ JGH } & \multicolumn{2}{|c|}{$\mathrm{B} 1,000$} & \multicolumn{2}{|c|}{ BGPR } & \multicolumn{2}{|c|}{$\mathrm{H}$} \\
\hline & $\begin{array}{l}\text { MP } \\
(\%)\end{array}$ & $\begin{array}{l}\text { HP } \\
(\%)\end{array}$ & $\begin{array}{l}\text { MP } \\
(\%)\end{array}$ & $\begin{array}{l}\text { HP } \\
(\%)\end{array}$ & $\begin{array}{l}\text { MP } \\
(\%)\end{array}$ & $\begin{array}{l}\text { HP } \\
(\%)\end{array}$ & $\begin{array}{l}\text { MP } \\
(\%)\end{array}$ & $\begin{array}{l}\text { HP } \\
(\%)\end{array}$ & $\begin{array}{l}\text { MP } \\
(\%)\end{array}$ & $\begin{array}{l}\text { HP } \\
(\%)\end{array}$ \\
\hline F1-Fatmawati/Inpago Unram I & 14.1 & 0.4 & -21.6 & -47.8 & 0.6 & -5.2 & -3.6 & -7.9 & -4.3 & -9.5 \\
\hline F1-Fatmawati/ G9 & 15.9 & -0.6 & -13.3 & -36.4 & 1.8 & -0.3 & 5.5 & -2.3 & 6.9 & -2.8 \\
\hline F1-Inpago Unram I/Fatmawati & -10.4 & -21.2 & -33.8 & -55.9 & -1.3 & -6.9 & -0.4 & -4.9 & -0.1 & -5.9 \\
\hline F1-G9/Fatmawati & -14.8 & -26.9 & -52.9 & -65.4 & 0.7 & -1.4 & -14.4 & -20.7 & -17.9 & -25.4 \\
\hline F1-IPB 3S/Inpago Unram I & 17.1 & 2.5 & -27.3 & -49.2 & 4.8 & -0.7 & 0.6 & -1.5 & 0.7 & -1.7 \\
\hline F1-IPB 3S/G9 & 16.8 & -0.5 & -13.7 & -32.6 & 2.7 & 1.1 & 2.5 & -7.4 & 3.1 & -8.9 \\
\hline F1-Inpago Unram 1/IPB 3S & -13.4 & -24.2 & -42.2 & -59.6 & -3.7 & -8.7 & 3.2 & 1.1 & 3.8 & 1.3 \\
\hline F1-G9/IPB 3S & -22.5 & -33.9 & -22.6 & -39.6 & 1.9 & 0.4 & -15.1 & -23.2 & -18.7 & -28.2 \\
\hline
\end{tabular}

Keterangan: JGI = Jumlah gabah isi per malai; JGH = Jumlah gabah hampa per malai; 1,000 = Bobot 1,000 butir gabah isi; BGPR = Berat gabah per rumpun; $\mathrm{H}=\mathrm{Hasil} ; \mathrm{MP}=$ heterosis berdasarkan rerata kedua tetua (mid parent heterosis); $\mathrm{HP}=\mathrm{heterosis}$ berdasarkan tetua tertinggi/heterobeltiosis (high parent heterosis) 
Tabel 4. Warna pericap beras dari tetua, F1 serta persilangan F1-resiprok

\begin{tabular}{llll}
\hline \multirow{2}{*}{ Persilangan } & & Fenotipe & F1 \\
\cline { 2 - 4 } Fatmawati/Inpago Unram 1 & Betina & Jantan & Putih \\
Inpago Unram 1/Fatmawati & Putih & Merah & Merah \\
(Resiprok) & Merah & Putih & Putih \\
Fatmawati/G9 & & Merah & Merah \\
G9/Fatmawati (resiprok) & Putih & Putih & Putih \\
IPB 3S/Inpago Unram 1 & Merah & Merah & Merah \\
Inpago Unram 1/IPB 3S (resiprok) & Putih & Putih & Putih \\
IPB 3S/G9 & Merah & Merah & Merah \\
G9/IPB 3S (resiprok) & Putih & Putih & \\
\hline
\end{tabular}

\section{KESIMPULAN}

Berdasarkan keragaan fenotipe $\mathrm{F} 1$ dan heterosis karakter bobot gabah per rumpun, bobot 1,000 butir gabah, jumlah gabah isi per malai, panjang malai, jumlah anakan produktif per rumpun, dan umur berbunga maka genotipe hasil persilangan F1-Fatmawati/G9, F1-Inpago Unram-I/ IPB 3S; dan F1-IPB 3S/Inpago Unram-I, berpeluang untuk menghasilkan galur-galur harapan padi beras merah semi tipe ideal dengan potensi hasil gabah tinggi.

\section{UCAPAN TERIMA KASIH}

Ucapan terima kasih disampaikan kepada Dirjen Pendidikan Tinggi, Departemen Riset, Teknologi, dan Pendidikan Tinggi Republik Indonesia yang telah mendanai penelitian ini melalui skim Penelitian Strategis Nasional tahun 2016, atas nama I Gusti Putu Muliarta Aryana dan kawan-kawan.

\section{DAFTAR PUSTAKA}

Aryana, I.G.P.M. 2009. Adaptasi dan stabilitas hasil galurgalur padi beras merah pada tiga lingkungan tumbuh. J. Agron. Indonesia 37:95-100.

Aryana, I.G.P.M. 2012. Peranan pemuliaan padi dalam mendukung ketahanan pangan. hal. 21-27. Dalam. Soewarto, N. Farid, T. Agung (Eds.). Prosiding Seminar Nasional peran pertanian dalam menunjang ketahan pangan dan energy untuk memperkuat ekonomi nasional berbasis sumber daya lokal. Purwokerto 19 September 2012.

Ashfag M., M.S. Haider, A.S. Kahan, S.U. Allah. 2013. Heterosis studies for various morphological traits of basmati rice germplasm under water stress conditions. J. Animal Plant Sci. 23:1131-1139.

Bobihoe, J., Nafisah. 2008. Keragaan galur-galur unggul padi di dataran tinggi Kerinci kabupaten Kerinci propinsi Jambi hal. 208-216. Dalam Suprihatno,
B.A., Daradjat, H. Suharto, H.M. Toha, A. Setyono, Suprihanto, A.S. Yahya (Eds.). Prosiding Inovasi teknologi padi mengantisipasi perubahan iklim global mendukung ketahan pangan. Sukamandi 2324 Juli 2008.

Chandrasari, S.E., Nasrullah, Sutardi. 2013. Uji daya hasil delapan galur harapan padi sawah. Vegetalika 1:99107 .

Darlina, A., A. Baihaki, A.A. Darajat, T. Herawati. 1992. Daya gabung dan heterosis karakter hasil dan komponen hasil enam genotipe kedelai dalam silang dialel. Zuriat 3:32-38.

Dewi, I.S., E.D. Lestari, Chaerani, R. Yunita. 2015. Penampilan galur harapan mutan diploid padi tipe baru di Sulawesi Selatan. J. Agron. Indonesia 43:8998.

Endrizal, J. Bobihoe. 2007. Pengujian beberapa galur unggulan padi dataran tinggi di Kabupaten Kerinci Propinsi Jambi, Balai Pengkajian Teknologi Pertanian, Jambi.

Ekeleme, F., A.Y. Kamara, S.O. Oikeh, S.O. Chikove, L.O. Omogui. 2007. Effect of weed competition on upland rice production in North-Eastern Nigeria. Afr. Crop Sci.Conference Proc.: 61-65.

Fatimaturrohmah, S., I.A. Rumanti, A. Soegianto, Damanhuri. 2016. Uji daya hasil lanjutan beberapa genotipe padi (Oryza sativa L.) hibrida di dataran medium. Produksi Tanaman. 4:129-136.

Fehr, W.R. 1987. Heterosis in: Principles of cultivar developmen. Theory and techniques (vol 1). Macmillan Publishing Company. New York.

Hao, X.B., X.F. Ma, P.S. Hu, Z.X. Zhang, G.M. Sui, Z.T. Hua. 2010. Relationship between plant type and grain 
quality of japonica hybrid rice in Northern China. Rice Sci.17:43-50.

Herawati, R., B.S. Purwoko, I.S. Dewi. 2009. Keragaman genetik dan karakter agronomi galur haploid ganda padi gogo dengan sifat tipe baru hasil kultur antera. J. Agron. Indonesia 37:87-94.

Huang, Z., Zhao B., L. Qi-ming, Fu X., Xin Y., Yuan L. 2015. Heterosis expression of hybrid rice in natural and short-day length conditions. Rice Sci. 22:81-88.

Ishak. 2012. Sifat agronomis, heritabilitas dan interaksi GxE galur mutan padi gogo (Oryza sativa L.). J. Agron. Indonesia 40:105-11.

Islam, M.S., S.Peng, R.M. Visperas, M.S.U. Bhuiya, S.M.A.T. Hossain, A.W. Julqiuar. 2010. Comparative study on yield and yield attributes of hybrid, inbred, and NPT rice genotypes in a tropical irrigated ecosystem. Bangladesh J. Agric. Res. 35:343-353.

Kumar, B.M.D., Y.G. Shadakshari, S.L. Krishnamurti. 2010. Genotype $\mathrm{x}$ environment interaction and stability analysis for grain yield and its components in Halugidda local rice mutants. J. Plant Sci. 1:12861289.

Ma, J., W. Ma, D. Ming, S. Yang, Q.Zhu. 2006. Characteristics of rice plant with heavy panicle. Agric. Sci. China. 5:101-105.

Makarim, A.K., E. Suhartatik. 2009. Morfologi dan fisiologi tanaman padi. p. 295-330. Dalam Suyanto, INyoman Widiarta, Satoto (Ed.). Padi: Inovasi teknologi dan ketahanan pangan. Buku 1. LIPI Press. Jakarta.

Mara, K.K.S., B.S. Purwoko, E. Sulistyono, I.S. Dewi. 2015. Penampilan agronomi dan uji toleransi naungan galur dihaploid padi gogo hasil cultur antera. J. Agron. Indonesia 43:1-7.

Nasir, M. 2009. Pengantar Pemuliaan Tanaman. Direktorat Jendral Pendidikan Tinggi, Departemen Pendidikan Nasional. Jakarta.

Peng, S., G.S. Khush, P. Virk, Q. Tang, Y. Zau. 2008. Progress in idiotype breeding to increase rice yield potential (Review). Field Crop Res.108:32-38.

Perera, U.I.P., A.P. Bentota, D. Ratnasekara, S.G.J.N. Senanayake. 2013. Heterosis in F1 generation of two indica rice crosses for growth and yield characteristyping. J. Agric. Sci. 8:138-141.

Rahimi, M., B. Rabiei, H. Samizadeh, A. K. Ghasemi. 2010. Combining ability and heterosis in rice (Oryza sativa L.) cultivar. J. Agr. Sci. Tech. 12:223-231.
Rahman, M.M., M.S. Naher, M.S.I. Sikdar, M.G. Azam, M.A. Hasan. 2015. Genetic characterization of red pericap trait in rice. J. Sci. Technol. 13:118-121.

Silfianah, H., Z. Millah, R.F. Yenny. 2012. Pengaruh tetua betina pada pewarisan ketahanan cabai terhadap chili vein mottle virus dalam populasi persilangan PBC495XPBC275. J. Ilmu Pert. Perikanan 1: 43-47.

Sholekha, U., N. Basuki, Kuswanto. 2015. Analisis daya gabung galur mandul jantan dan heterosis pada 12 padi hibrida (Oryza sativa L.). J. Produksi Tanaman. 3:225-232.

Suprihatno, B., A.A. Daradjat, Satoto, S.E. Baehaki, A. Setyono, S.D. Indrastuti, P. Wardana, H. Sembiring. 2010. Deskripsi Varietas Padi. Balai Besar Penelitian Tanaman Padi Badan Penelitian dan Pengembangan Pertanian Kementerian Pertanian.

Sutaryo, B. 2014. Penampilan agro-morfologi dan parameter genetik 12 genotipe padi di sawah berpengairan teknis. J. Ilmu Pertanian 17:13-24.

Thamrin, T., R. Soehendi, Y. Hutapea. 2010. Keragaan galurgalur harapan padi gogo lahan kering di Sumatera Selatan. hal. 263-274. Dalam Suprihatno.B., Aadjat, Satoto, Baehaki, Sudir (Eds.). Prosiding Seminar Nasional Hasil Penelitian Padi, Inovasi Teknologi Padi untuk Mempertahankan Swasembada dan Mendorong Ekspor Beras. Sukamandi 28 Oktober 2009.

Tulu. L. 2001. Hetrosis and genetic diversity in crosses of seven East African maize (Zea mays L.) populations. p.125-129. In Seventh Eastern and Southern African Regional Maize Conference, $11^{\text {th }}-15^{\text {th }}$ February 2001.

Virnani, S.S, J.B. Young, H.P. Moon, I. Kumar, J.C. Flinn. 1991. Increasing rice yields throught exploitation of heterosis. IRRI. Res. P. Series.

Yang, W., S. Peng, R.C Laza, R.M. Visperas, M.L.D. Sese. 2007. Grain yield and yield atributes of new plant type and hybrid rice. Crop. Sci. 47:1393-1400.

Yunita, A., D. Harnowo. 2010. Teknologi Budidaya Padi Sawah mendukung SL-PTT. BPTP Sumatera Utara.

Zen, S. 2013. Penampilan galur harapan padi sawah di Kabupaten Solok Sumatra Barat. J. Penelitian Pertanian Terapan 13:38-44.

Zhengjin, X.U., C. Wenfu, Z Longbu, Y. Shouren. 2005, Design principles and parameters of rice ideal panicle type. Chinese Sci. Bull. 50:225-2256. 